\title{
Tingkat Kepuasan Dokter dan Perawat Poliklinik Terhadap Pelayanan Rekam Medis di RSUD dr. R. Goeteng Taroenadibrata Purbalingga
}

\author{
Zain Azmii Nadhiirah Fathoni ${ }^{1}$, Akhmadi $^{2}$ \\ Program Studi Diploma Rekam Medis ${ }^{1}$, Bagian Ilmu Keperawatan FK UGM ${ }^{2}$ \\ zazainazmii9@yahoo.com ${ }^{1}$,akhmadiugm@gmail.com ${ }^{2}$
}

\begin{abstract}
ABSTRAK
Latar Belakang: Setiap fasilitas kesehatan memiliki berbagai bagian pelayanan yang berkesinambungan satu sama lain dan tidak dapat berdiri sendiri. Setiap pelayanan harus saling melengkapi demi terciptanya mutu pelayanan yang baik untuk penyembuhan pasien. Dalam peningkatan kualitas mutu pelayanan, hubungan antar tenaga kesehatan dalam satu fasilitas kesehatan harus baik. Salah satunya hubungan antara perekam medis dengan dokter dan perawat. Oleh karena itu, penilaian internal oleh dokter dan perawat terhadap pelayanan rekam medis di RSUD dr. R. Goeteng Taroenadibrata Purbalingga sangat dibutuhkan untuk meningkatkan mutu pelayanan rekam medis di rumah sakit tersebut.

Tujuan: Mengetahui tingkat kepuasan dokter dan perawat terhadap pelayanan rekam medis di RSUD dr. R. Goeteng Taroenadibrata Purbalingga berdasarkan dimensi kualitas jasa/ pelayanan.

Metode: Jenis penelitian yang dilakukan menggunakan penelitian kuantitatif deskriptif. Responden dari penelitian ini adalah dokter dan perawat poliklinik RSUD dr. R. Goeteng Taroenadibrata Purbalingga berjumlah 42 orang. Teknik pengambilan data menggunakan kuisioner (angket).

Hasil: Hasil dari penelitian ini adalah tingkat kepuasan dokter dan perawat poliklinik terhadap pelayanan rekam medis secara keseluruhan berada dalam kategori cukup puas. Dengan masing-masing persentase pada setiap dimensi yaitu dimensi penampilan sebesar 50,00\%, dimensi keandalan sebesar 47,62\%, dimensi ketanggapan sebesar 40,48\%, dimensi kepastian sebesar $45,24 \%$, dan dimens empati sebesar $42,86 \%$.
\end{abstract}

Kesimpulan: Setiap dimensi kualitas pelayanan berada dalam kategori cukup puas.

Persentase terendah berada pada dimensi ketanggapan.

Kata Kunci: Tingkat Kepuasan, Rekam Medis

\begin{abstract}
Background: Every health facility has various sections of continuous service to one another and can not stand alone. Each service should complement each other in order to create good quality service for patient healing. In improving the quality of service quality, the relationship between health personnel in the health facility should be good. One was the relationship between medical recorder with doctors and nurses. Therefore, internal assessment by doctors and nurses on medical record service in RSUD dr. R. Goeteng Taroenadibrata Purbalingga is needed to improve the quality of service of medical records at the hospital.
\end{abstract}

Objective: To determine the level of satisfaction of doctors and nurses for the services of medical records in RSUD dr. R. Goeteng Taroenadibrata Purbalingga based on the dimensions of quality of service.

Methods: The research is conducted using descriptive quantitative research. The respondents of this research are doctors and nurses in outpatient of RSUD $d r . R$. Goeteng Taroenadibrata Purbalingga for 42 peoples. Data collection techniques using a questionnaire.

Results: Results of this study was the level of satisfaction of doctors and nurses in outpatient for medical record service as a whole are in a satisfied category. With each percentage are tangible dimension of $50.00 \%$, amounting to $47.62 \%$ for reliability dimension, the dimension of responsiveness by $40.48 \%$, amounting to $45.24 \%$ for assurance dimension, and empathy dimension by $42.86 \%$.

Conclusion: Each dimension of service quality are in a satisfied category. Lowest percentage is the dimension of responsiveness.

Keywords: Satisfaction, Medical Record 


\section{PENDAHULUAN}

\section{A. Latar Belakang}

Fasilitas kesehatan adalah fasilitas pelayanan kesehatan yang digunakan untuk menyelenggarakan upaya pelayanan kesehatan perorangan, baik promotif, preventif, kuratif maupun rehabilitatif yang dilakukan oleh pemerintah, pemerintah daerah, dan masyarakat (Kemenkes, 2013). Setiap fasilitas kesehatan memiliki berbagai bagian pelayanan yang saling berkesinambungan satu sama lain dan tidak dapat berdiri sendiri, termasuk rumah sakit.

Menurut UU nomor 36 tahun 2014, dokter, perawat, dan perekam medis termasuk dalam jenis tenaga kesehatan. Dalam peningkatan kualitas mutu pelayanan, hubungan antar tenaga kesehatan dalam satu fasilitas kesehatan juga harus baik. Salah satunya hubungan antara perekam medis dengan dokter dan perawat.

Berdasarkan hasil observasi ketika melakukan kerja pengabdian, hal yang sering dikeluhkan antara lain pendistribusian rekam medis yang lama, pengambilan berkas rekam medis yang tidak sesuai dengan kebutuhan dokter dan perawat, serta berkas rekam medis yang tidak tertata secara rapi. Pelayanan yang tidak sesuai dengan kebutuhan dokter dan perawat dapat menghambat pelayanan di rumah sakit sehingga mempengaruhi kualitas pelayanan di rumah sakit tersebut. Dengan adanya permasalahan tersebut, maka dilakukan penelitian dengan judul "Tingkat Kepuasan Dokter dan Perawat Poliklinik Terhadap Pelayanan Rekam Medis di RSUD dr. R. Goeteng Taroenadibrata Purbalingga".

\section{B. Rumusan Masalah}

Bagaimana tingkat kepuasan dokter dan perawat poliklinik terhadap pelayanan rekam medis di RSUD dr. R. Goeteng Taroenadibrata Purbalingga?

C. Tujuan

Mengetahui tingkat kepuasan dokter dan perawat poliklinik terhadap pelayanan rekam medis di RSUD dr. R. Goeteng Taroenadibrata Purbalingga berdasarkan 5 (lima) dimensi pelayanan/ jasa.

\section{Manfaat}

1. Sebagai gambaran dan tolak ukur dalam pengembangan institusi di bidang pendidikan.

2. Sebagai bahan evaluasi bagi rumah sakit untuk memajukan kualitas rumah sakit, terutama kualitas asuhan pelayanan rekam medis di rumah sakit.

3. Memberikan kesempatan dalam membandingkan teori yang telah dipelajari pada saat perkuliahan dengan pelaksanaan di rumah sakit.

\section{METODE}

\section{A. Populasi dan Sampel}

Populasi dari penelitian ini adalah seluruh dokter dan perawat poliklinik di RSUD dr. R. Goeteng Taroenadibrata Purbalingga. Sampel dalam penelitian ini adalah seluruh dokter dan perawat poliklinik di RSUD dr. R. Goeteng Taroenadibrata Purbalingga dengan jumlah responden 42 orang yang telah menyetujui surat persetujuan responden.

\section{B. Instrumen Penelitian}

Instrumen penelitian ini adalah kuisioner yang disusun berdasarkan indikator-indikator dari variable penelitian. Indikator tersebut dituangkan secara rinci dalam butirbutir pernyataan yang berupa angket dan dibagikan kepada responden. Penetapan skor yang diberikan pada tiap-tiap butir instrumen dalam penelitian ini, responden diminta untuk mengisi setiap butir-butir penyataan dengan memilih salah satu dari lima pilihan yang tersedia. Penyekoran dan pengukuran pada alternatif jawaban menggunakan skala Likert yang memiliki lima alternatif jawaban yaitu sangat puas, puas, cukup puas, tidak puas, dan sangat tidak puas.

\section{Teknik Pengambilan Data}

Teknik pengambilan data yang digunakan dalam penelitian ini adalah kuisioner (angket) yang merupakan teknik pengumpulan data yang 
dilakukan dengan cara memberi seperangkat pertanyaan atau pernyataan tertulis kepada responden untuk dijawabnya (Sugiyono, 2011).

D. Teknik Analisis Data

Teknik analisis data pada penelitian ini secara umum menggunakan teknik statistik deskriptif. Penyajian data dalam statistik deskripif ini menggunakan tabel yang berisi persentase kepuasan dari setiap dimensi. Data yang diperoleh dari kuisioner penelitian akan dikelompokkan berdasarkan dimensi kualitas jasa. Masing-masing jawaban dari pernyataan pada kuisioner diberikan skor sesuai dengan kelompok skala Likert. Dari jumlah skor setiap dimensi diperoleh rentang skor, dimana hasilnya diubah menjadi skala persentase.

\section{HASIL DAN PEMBAHASAN}

\section{A. Hasil}

Mutu pelayanan kesehatan adalah suatu langkah peningkatan pelayanan kesehatan untuk mencapai tujuan yang diharapkan sesuai dengan pengetahuan yang dimiliki oleh tenaga kesehatan. Salah satu penggambaran mutu adalah adanya manajemen utilisasi yang menggambarkan efisiensi penggunaan sumber daya dari suatu pelayanan kesehatan, hal ini terkait dengan ketepatan informasi yang digunakan untuk melakukan pengukuran sesuai indikator penilaian yang digunakan (Hatta, 2010). Salah satu penilaian mutu pelayanan kesehatan adalah dengan pengukuran tingkat kepuasan petugas medis terhadap pelayanan rekam medis. Berdasarkan hasil penelitian yang dilakukan terhadap 42 responden, tingkat kepuasan untuk masing-masing dimensi kualitas jasa adalah sebagai berikut:

\section{Dimensi Tangible (Penampilan)}

Yaitu pelayanan yang dapat dilihat (berwujud) meliputi penampilan fisik dari fasilitas, peralatan, karyawan dan alat-alat komunikasi.
Tabel 1. Tingkat Kepuasan Berdasarkan Dimensi Tangible (Penampilan)

\begin{tabular}{clcc} 
No & $\begin{array}{c}\text { Kategori } \\
\text { jawaban }\end{array}$ & \multicolumn{2}{c}{ Kepuasan } \\
\cline { 3 - 4 } 1. & Sangat Puas & 0 & 0 \\
2. & Puas & 15 & 35,71 \\
3. & Cukup Puas & 20 & 47,62 \\
4. & Tidak Puas & 7 & 16,67 \\
5. & Sangat Tidak & 0 & 0 \\
& Puas & & \\
\hline
\end{tabular}

Berdasarkan distribusi frekuensi yang terangkum dalam tabel distribusi frekuensi di atas dapat diketahui bahwa kepuasan dokter dan perawat poliklinik berdasarkan dimensi tangible (penampilan) berada dalam kategori cukup puas dengan persentase tertinggi yaitu sebesar 50,00\% (21 responden). Untuk kategori sangat puas hanya $4,76 \%$ (2 responden), kategori puas sebesar $35,71 \%$ (15 responden), dan kategori tidak puas sebesar 9,52\% (4 responden).

2. Dimensi Reliability (Keandalan)

Yaitu dimensi yang mengukur keandalan suatu pelayanan jasa kepada konsumen. Dimensi keandalan didefinisikan sebagai kemampuan untuk memberikan jasa yang dijanjikan dengan terpercaya dan akurat.

Tabel 2. Tingkat Kepuasan Berdasarkan Dimensi Reliability (Keandalan)

\begin{tabular}{clcc} 
No & $\begin{array}{c}\text { Kategori } \\
\text { jawaban }\end{array}$ & \multicolumn{2}{c}{ Kepuasan } \\
\cline { 3 - 4 } 1. & Sangat Puas & 2 & 4,76 \\
2. & Puas & 15 & 35,71 \\
3. & Cukup Puas & 21 & 50,00 \\
4. & Tidak Puas & 4 & 9,52 \\
5. & Sangat Tidak & 0 & 0 \\
& Puas & & \\
\end{tabular}

Berdasarkan distribusi frekuensi yang terangkum dalam tabel distribusi frekuensi di atas dapat diketahui bahwa kepuasan dokter dan perawat poliklinik berdasarkan dimensi reliability (keandalan) berada dalam kategori cukup puas dengan persentase tertinggi yaitu sebesar $47,62 \%$ (20 responden). Untuk kategori puas sebesar 35,71\% 
(15 responden) dan kategori tidak puas sebesar $16,67 \%$ (7 responden).

3. Dimensi (Ketanggapan)

Responsiveness

Yaitu kemauan untuk membantu dan memberikan jasa dengan cepat kepada konsumen yang meliputi kesiapan tenaga kerja dalam melayani konsumen serta kecepatan tenaga kerja dalam menangani transaksi dan penanganan atas keluahan konsumen. Dimensi daya tanggap merupakan dimensi yang bersifat paling dinamis. Hal ini dipengaruhi oleh faktor perkembangan teknologi.

Tabel 3. Tingkat Kepuasan Berdasarkan Dimensi Responsiveness (Ketanggapan)

\begin{tabular}{clcc}
\hline No & $\begin{array}{c}\text { Kategori } \\
\text { jawaban }\end{array}$ & \multicolumn{2}{c}{ Kepuasan } \\
\cline { 3 - 4 } 1. & Sangat Puas & 2 & 4,76 \\
2. & Puas & 17 & 40,48 \\
3. & Cukup Puas & 19 & 45,24 \\
4. & Tidak Puas & 4 & 9,52 \\
5. & Sangat Tidak & 0 & 0 \\
& Puas & & \\
\hline
\end{tabular}

Berdasarkan distribusi frekuensi yang terangkum dalam tabel distribusi frekuensi di atas dapat diketahui bahwa kepuasan dokter dan perawat poliklinik berdasarkan dimensi responsiveness (ketanggapan) berada dalam kategori cukup puas dengan persentase tertinggi yaitu sebesar $40,48 \%$ (17 responden). Untuk kategori sangat puas hanya 2,38\% (1 responden), kategori puas sebesar 38,10\% (16 responden), dan kategori tidak puas sebesar $19,05 \%$ (8 responden).

\section{Dimensi Assurance (Kepastian)}

Yaitu dimensi kualitas pelayanan yang berhubungan dengan kemampuan dalam menanamkan kepercayaan dan keyakinan kepada konsumen. Dimensi kepastian meliputi kemampuan tenaga kerja atas pengetahuan terhadap produk meliputi kemampuan pengetahuan karyawan terhadap produk secara tepat, kualitas keramah-tamahan, perhatian dan kesopanan dalam memberikan pelayanan, keterampilan dalam memberikan pelayanan, keterampilan dalam memberikan keamanan di dalam memanfaatkan jasa yang ditawarkan serta kemampuan di dalam menanamkan kepercayaan konsumen terhadap jasa yang ditawarkan. Dimensi kepastian atau jaminan ini merupakan gabungan dari aspek-aspek berikut ini: a. Kompetensi (competence), b. Kesopanan (coutesy), c. Kredibilitas (credibility), d. Keamanan (security).

\begin{tabular}{clcc}
\multicolumn{2}{c}{ Tabel 4. Tingkat Kepuasan Berdasarkan } \\
\multicolumn{3}{c}{ Dimensi Assurance (Kepastian) } \\
\hline No & \multicolumn{1}{c}{ Kategori } & \multicolumn{2}{c}{ Kepuasan } \\
\cline { 3 - 4 } & jawaban & Frekuensi & Presentase \\
\hline 1. & Sangat Puas & 1 & 2,38 \\
2. & Puas & 16 & 38,10 \\
3. & Cukup Puas & 17 & 40,48 \\
4. & Tidak Puas & 8 & 19,05 \\
5. & Sangat Tidak & 0 & 0 \\
& Puas & & \\
\hline
\end{tabular}

Berdasarkan distribusi frekuensi yang terangkum dalam tabel distribusi frekuensi di atas dapat diketahui bahwa kepuasan dokter dan perawat poliklinik berdasarkan dimensi assurance (kepastian) berada dalam kategori cukup puas dengan persentase tertinggi yaitu sebesar 45,24\% (19 responden). Untuk kategori sangat puas hanya $4,76 \%$ (2 responden), kategori puas sebesar 40,48\% (17 responden), dan kategori tidak puas sebesar 9,52\% (4 responden).

\section{Dimensi Empathy (Empati)}

Merupakan kesediaan untuk peduli dan memberikan perhatian pribadi kepada pengguna jasa. Pelayanan yang empatik sangat memerlukan sentuhan/perasaan pribadi. Dimensi empati adalah dimensi yang memberikan peluang besar untuk menciptakan pelayanan yang mengejutkan yaitu 
sesuatu yang tidak diharapkan pengguna jasa tetapi ternyata diberikan oleh penyedia jasa. Dimesi empati ini merupakan gabungan dari aspek berikut ini: a. Akses (access), b. Komunikasi (communication), c. Pemahaman pada konsumen (understanding the costumer).

Tabel 5. Tingkat Kepuasan Berdasarkan Dimensi Empathy (Empati)

\begin{tabular}{clcc}
\hline No & $\begin{array}{c}\text { Kategori } \\
\text { jawaban }\end{array}$ & \multicolumn{2}{c}{ Kepuasan } \\
\cline { 3 - 4 } & Frekuensi & Presentase \\
\hline 1. & Sangat Puas & 3 & 7,14 \\
2. & Puas & 17 & 40,48 \\
3. & Cukup Puas & 18 & 42,86 \\
4. & Tidak Puas & 4 & 9,52 \\
5. & Sangat Tidak & 0 & 0 \\
& Puas & & \\
\hline
\end{tabular}

Berdasarkan distribusi frekuensi yang terangkum dalam tabel distribusi frekuensi di atas dapat diketahui bahwa kepuasan dokter dan perawat poliklinik berdasarkan dimensi empathy (empati) berada dalam kategori cukup puas dengan persentase tertinggi yaitu sebesar $42,86 \%$ (18 responden). Untuk kategori sangat puas hanya $7,14 \%$ (3 responden), kategori puas sebesar 40,48\% (17 responden), dan kategori tidak puas sebesar $9,52 \%$ (4 responden).

\section{B. Pembahasan}

Dari 5 dimensi pada variabel kualitas pelayanan yaitu tangible (penampilan), reliability (keandalan), responsiveness (ketanggapan), assurance (kepastian), empathy (empati) menunjukkan bahwa dimensi tangible (penampilan) menunjukkan persentase tertinggi untuk kategori cukup puas. Hal tersebut dikarenakan penilaian untuk dimensi tangible (penampilan) merupakan pelayanan yang dapat dilihat (berwujud) meliputi penampilan fisik dari fasilitas, peralatan, karyawan, dan alat komunikasi yang dapat diperbaharui sesuai perkembangan zaman. Berdasarkan hasil observasi, terdapat komputer dalam ruang penyimpanan berkas rekam medis yang dapat digunakan untuk melacak berkas rekam medis yang tidak ada pada rak penyimpanan. Komputer tersebut dapat membantu petugas filing dalam pencarian berkas rekam medis. Hasil penelitian tersebut berbeda dengan penelitian Shidiq (2014) dengan judul Tingkat Kepuasan Perawat Bangsal Terhadap Pelayanan Petugas Rekam Medis di RSJD Dr. RM Soejarwadi Provinsi Jawa Tengah yang menunjukkan bahwa persentase tertinggi dari 5 (lima) dimensi kualitas pelayanan adalah reliability (keandalan).

Dalam penelitian ini, untuk dimensi reliability (keandalan) tidak mencapai persentase tertinggi. Hal tersebut berbeda dengan penelitian Shidiq (2014) yang menunjukkan bahwa dimensi reliability (keandalan) mencapai persentase tertinggi. Dimensi reliability (keandalan) mengukur mengenai kemampuan petugas dalam memberikan jasa yang dijanjikan dengan terpercaya dan akurat. Untuk dimensi assurance (kepastian) tidak berbeda dengan penelitian Shidiq (2014) yang menunjukkan bahwa dimensi tersebut tidak berada pada persentase tertinggi maupun terendah dalam kategori cukup puas. Dimensi assurance (kepastian) merupakan dimensi yang berhubungan dengan kemampuan dalam menanamkan kepercayaan dan keyakinan kepada konsumen. Selain itu, untuk dimensi empathy (empati) merupakan dimensi terendah dalam penelitian Shidiq (2014). Dimensi empathy (empati) merupakan kesediaan untuk peduli dan memberikan perhatian pribadi kepada pengguna jasa.

Sedangkan pada penelitian ini, dimensi responsiveness (ketanggapan) menunjukkan persentase terendah untuk kategori cukup puas. Dimensi responsiveness (ketanggapan) masih menjadi daya tarik utama bagi pemilihan pelanggan untuk memilih layanan yang diinginkan. Hasil dari 
penelitian menunjukkan bahwa harapan dokter dan perawat pada petugas rekam medis lebih mengutamakan dimensi ketanggapan, yaitu kemauan untuk membantu dan memberikan jasa dengan cepat kepada konsumen. Berdasarkan observasi yang dilakukan, sudah terdapat SOP mengenai waktu pendistribusian berkas rekam medis ke poliklinik yang sesuai dengan peraturan yang berlaku. Tetapi ruang penyimpanan berkas rekam medis tidak berada di tengah tempat pelayanan rumah sakit. Hal tersebut membutuhkan alat distribusi untuk mempercepat pendistribusian berkas rekam medis ke poliklinik. Berdasarkan hasil observasi, alat distribusi yang digunakan kurang memadai dalam membantu pendistribusian berkas rekam medis karena alat tersebut sering rusak sehingga mengahambat pendistribusian berkas rekam medis. Melakukan jual beli jasa di suatu perusahaan (rumah sakit) yang memiliki daya tanggap yang baik akan membuat pelanggan merasa puas dan akan loyal kepada penyedia jasa tersebut. Hasil penelitian ini berbeda dengan penelitian terdahulu yang dilakukan oleh Shidiq (2014) yang menunjukkan persentase terendah untuk 5 (lima) dimensi kualitas pelayanan adalah dimensi reliability (keandalan).

Berdasarkan hasil analisis deskriptif yang telah dilakukan, diperoleh hasil bahwa tingkat kepuasan dokter dan perawat poliklinik terhadap pelayanan rekam medis ditinjau dari dimensi tangible (penampilan) berada dalam kategori cukup puas $(50,00 \%)$ atau setengah dari keseluruhan rsponden. Sedangkan tingkat kepuasan dokter dan perawat poliklinik terhadap pelayanan rekam medis ditinjau dari dimensi reliability (keandalan) berada dalam kategori cukup puas $(47,62 \%)$, dimensi responsiveness (ketanggapan) berada dalam kategori cukup puas (40,48\%), dimensi assurance (kepastian) berada dalam kategori cukup puas
(45,24\%), dimensi empathy (empati) berada dalam kategori cukup puas $(42,86 \%)$, persentase tersebut mengartikan bahwa hampir setengah dari keseluruhan responden yang memilih kategori tersebut.

Hasil penelitian ini mendukung pendapat yang dikemukakan oleh Kotler (1993), bahwa salah satu cara membedakan sebuah perusahaan penyedia jasa adalah memberikan jasa dengan kualitas yang lebih tinggi daripada pesaing mereka secara konsisten. Lebih lanjut, Tjiptono (2000) juga mengemukakan bahwa kualitas jasa bukanlah diukur dari sudut penyedia jasa saja, tetapi berdasarkan sudut pandang/persepsi pelanggan. Hal ini karena pelangganlah yang membeli dan memakai jasa sehingga sudah seharusnya penilaian kualitas jasa dilakukan oleh mereka. Pada dasarnya pelanggan adalah pembeli tetap yang berkemampuan membeli dan melaksanakan pembelian pada perusahaan.

\section{PENUTUP}

\section{A. Kesimpulan}

1. Tingkat kepuasan dokter dan perawat poliklinik terhadap pelayanan rekam medis ditinjau dari dimensi tangible (penampilan) berada dalam kategori cukup puas (50,00\%). Dimensi ini menjadi dimensi dengan persentase tertinggi. Hal tersebut dikarenakan penilaian untuk dimensi tangible (penampilan) merupakan pelayanan yang dapat dilihat (berwujud) meliputi penampilan fisik dari fasilitas, peralatan, karyawan, dan alat komunikasi yang dapat diperbaharui sesuai perkembangan zaman.

2. Tingkat kepuasan dokter dan perawat poliklinik terhadap pelayanan rekam medis ditinjau dari dimensi reliability (keandalan) berada dalam kategori cukup puas $(47,62 \%)$.

3. Tingkat kepuasan dokter dan perawat poliklinik terhadap 
pelayanan rekam medis ditinjau dari dimensi responsiveness (ketanggapan) berada dalam kategori cukup puas (40,48\%). Dimensi ini menjadi dimensi dengan persentase terendah. Berdasarkan hasil observasi, hal tersebut dikarenakan tata letak ruang penyimpanan yang tidak strategis tanpa didukung alat pendistribusian yang mendukung.

4. Tingkat kepuasan dokter dan perawat poliklinik terhadap pelayanan rekam medis ditinjau dari dimensi assurance (kepastian) berada dalam kategori cukup puas $(45,24 \%)$.

5. Tingkat kepuasan dokter dan perawat poliklinik terhadap pelayanan rekam medis ditinjau dari dimensi empathy (empati) berada dalam kategori cukup puas $(42,86 \%)$.

\section{B. Saran}

1. Bagi Rekam Medis

Secara keseluruhan, setiap dimensi kualitas jasa berada dalam kategori cukup puas, tetapi persentase untuk kategori tersebut belum mencapai nilai maksimum sehingga masih perlu adanya perbaikan terhadap pelayanan rekam medis di RSUD dr. R. Goeteng Taroenadibrata Purbalingga. Persentase terendah dari kelima dimensi kualitas jasa adalah dimensi ketanggapan (responsiveness). Dimensi ketanggapan (responsiveness) menggambarkan kemampuan untuk memberikan pelayanan dengan cepat kepada pasien. Dalam pelayanan rekam medis ditunjukkan dengan pendistribusian rekam medis ke poliklinik secara cepat dan tepat waktu. Untuk meningkatkan kecepatan dalam pendistribusian berkas rekam medis maka sebaiknya meninjau kembali tata letak ruang penyimpanan yang tidak strategis serta mengevaluasi alat pendistribusian berkas rekam medis sehingga mendukung pendistribusian berkas rekam medis dari ruang penyimpanan menuju poliklinik.

2. Bagi Peneliti Selanjutnya

Penelitian ini hanya menggunakan kuisioner sebagai teknik pengambilan data sehingga jawaban yang diberikan responden terbatas pada pernyataan yang ada di dalam kuisioner. Untuk peneliti selanjutnya, sebaiknya melakukan pengambilan data menggunakan teknik wawancara sehingga pernyataan yang diberikan responden tidak terbatas pada jawaban yang telah tersedia.

\section{DAFTAR PUSTAKA}

Hatta, G.R. (2010). Pedoman Manajemen Informasi Kesehatan di Sarana Pelayanan Kesehatan. Jakarta: Universitas Indonesia.

Kemenkes RI. (2013). Undang-Undang Nomor 71 Tahun 2013 tentang pelayanan kesehatan pada jaminan kesehatan nasional. Diakses dari www.depkes.go.id. pada tanggal 11 Januari 2016.

Sugiyono. (2011). Metode Penelitian Kuantitatif Kualitatif dan $R$ \& $D$. Bandung: Alfabeta.

Tjiptono, F. (2000). Strategi Pemasaran. Yogyakarta: Andi Offset. 